\title{
Cytophagic histiocytic panniculitis
}

INSERM

\section{Source}

INSERM. (1999). Orphanet: an online rare disease and orphan drug data base. Cytophagic histiocytic panniculitis. ORPHA:94087

Cytophagic histiocytic panniculitis (CHP) is a very rare form of panniculitis manifesting as recurrent multiple subcutaneous nodules (which may progressively become ecchymotic and ulcerated), and histologically characterized by lobular panniculitis with lymphocytic and histiocytic infiltration in the subcutaneous adipose tissue. 